\title{
The application of exosomes as a nanoscale cancer vaccine
}

\author{
This article was published in the following Dove Press journal: \\ International Journal of Nanomedicine \\ 23 October 2010 \\ Number of times this article has been viewed
}

\author{
Aaron Tan' \\ Hugo De La Peña ${ }^{2}$ \\ Alexander M Seifalian ${ }^{1,3}$ \\ 'UCL Division of Surgery and \\ Interventional Science, Centre for \\ Nanotechnology and Regenerative \\ Medicine, University College London, \\ London, UK; ${ }^{2}$ Department of \\ Pathology, University of Cambridge, \\ Cambridge, UK; ${ }^{3}$ Royal Free \\ Hampstead NHS Trust Hospital, \\ London, UK
}

\begin{abstract}
Cancer is a leading cause of death globally, and it is predicted and projected to continue rising as life expectancy increases. Although patient survival rates for some forms of cancers are high due to clinical advances in treatment protocols, the search for effective cancer vaccines remains the ultimate Rosetta Stone in oncology. Cervarix ${ }^{\circledR}$, Gardasil ${ }^{\circledR}$, and hepatitis B vaccines are currently employed in preventing certain forms of viral cancers. However, they are, strictly speaking, not 'true' cancer vaccines as they are prophylactic rather than therapeutic, are only effective against the oncogenic viruses, and do not kill the actual cancer cells. On April 2010, a new prostate cancer vaccine Provenge ${ }^{\circledR}$ (sipuleucel-T) was approved by the US FDA, and it is the first approved therapeutic vaccine that utilizes antigenpresenting cell technology involving dendritic cells in cancer immunotherapy. Recent evidence suggests that the use of nanoscale particles like exosomes in immunotherapy could form a viable basis for the development of novel cancer vaccines, via antigen-presenting cell technology, to prime the immune system to recognize and kill cancer cells. Coupled with nanotechnology, engineered exosomes are emerging as new and novel avenues for cancer vaccine development. Here, we review the current knowledge pertaining to exosome technology in immunotherapy and also seek to address the challenges and future directions associated with it, in hopes of bringing this exciting application a step closer toward an effective clinical reality.
\end{abstract}

Keywords: exosomes, cancer vaccine, immunotherapy, nanomedicine

\section{Introduction}

Cancer is a major global cause of morbidity and mortality, and it is expected to rise in the coming decades. ${ }^{1}$ Conventional treatments for cancer include the use of chemotherapeutic drugs, radiotherapy, and interventional surgery in the case of solid (and operable) tumors. Recent evidence suggests that the application of dendritic cell-derived exosomes (DEX), tumor cell-derived exosomes (TEX), and ascitic cell-derived exosomes (AEX) could emerge as novel nanoscale immunotherapy treatments for cancer, by priming the body's immune system to recognize and kill cancer cells (Table 1).

Exosomes are nanoscale $(50-100 \mathrm{~nm})$ membrane vesicles, first described by Rose Johnstone in the 1970s, and it is postulated that they are involved in cell-cell communication, although its exact biological function and mechanism has, to this day, yet to be fully elucidated. ${ }^{2}$ The canonical exosome is of intracellular origin and displays MHC class I and II. $^{3}$ It has also been shown to contain heat shock proteins and has a lipid composition rich in cholesterol, sphingomyelin, and ceramide. ${ }^{4}$ Its main protein markers are tetraspanins (CD63, CD9), Alix, and TSG101 and is able to mediate a
Correspondence: Alexander M Seifalian UCL Division of Surgery and Interventional Science, Centre for Nanotechnology and Regenerative Medicine, University College London, Pond Street, London NW3 2QG, UK Tel +44207830290I

Email a.seifalian@ucl.ac.uk 
Table I Overview of the application of exosomes as a nanoscale cancer vaccine

\begin{tabular}{|c|c|c|c|c|c|}
\hline $\begin{array}{l}\text { Exosome } \\
\text { type }\end{array}$ & Cancer type & Exosome purification & $\begin{array}{l}\text { Exosome derivation } \\
\text { and delivery }\end{array}$ & Results overview & References \\
\hline DEX & Melanoma & $\begin{array}{l}\text { Centrifugation up to } \\
100,000 \mathrm{~g} \\
30 \% \text { sucrose/ } \mathrm{D}_{2} \mathrm{O} \text { cushion } \\
\text { Treatment with PBS }\end{array}$ & $\begin{array}{l}\text { Exosomal MHC-peptide } \\
\text { complex pulsed with melanoma } \\
\text { antigen } \\
\text { CTL pulsed with } \\
\text { melanoma-primed-exosomes }\end{array}$ & $\begin{array}{l}\text { DC release exosomes to other } \\
\text { naïv DC for T-cell priming } \\
\text { Exosomes require mature DC } \\
\text { to promote differentiation of } \\
\text { melanoma-specific effector } \\
\text { T cell producing IFN- } \gamma \text { effector } \\
\text { lymphocytes }\end{array}$ & 47 \\
\hline AEX & Various & $\begin{array}{l}\text { Centrifugation up to } \\
100,000 \mathrm{~g} \\
30 \% \text { sucrose } / \mathrm{D}_{2} \mathrm{O} \text { cushion } \\
\text { Treatment with PBS }\end{array}$ & $\begin{array}{l}\text { DC pulsed with AEX } \\
\text { PBL stimulated with } \\
\text { AEX-pulsed DC }\end{array}$ & $\begin{array}{l}\text { Release of IFN- } \gamma \text { by PBL } \\
\text { Tumor cell lysis }\end{array}$ & 35 \\
\hline DEX & $\begin{array}{l}\text { Toxoplasma } \\
\text { gondii }\end{array}$ & $\begin{array}{l}\text { Centrifugation up to } \\
100,000 \mathrm{~g} \\
\text { Treatment with PBS }\end{array}$ & $\begin{array}{l}\text { DEX pulsed with } T \text {. gondii- } \\
\text { derived antigen }\end{array}$ & $\begin{array}{l}\text { Murine models' resistant brain } \\
\text { cyst formation normally caused } \\
\text { by } T \text {. gondii } \\
\text { Production of } T \text {. gondii-specific } \\
\text { antibody } \\
\text { Increased production of cytokines }\end{array}$ & 48 \\
\hline TEX & Leukemia & $\begin{array}{l}\text { Centrifugation up to } \\
100,000 \mathrm{~g} \\
30 \% \text { sucrose } / \mathrm{D}_{2} \mathrm{O} \text { cushion } \\
\text { Treatment with PBS }\end{array}$ & $\begin{array}{l}\text { Direct vaccination of murine } \\
\text { models with } T E X^{\prime}\end{array}$ & $\begin{array}{l}\text { Inhibition of tumor growth } \\
\text { CTL-induced lysis of cancer cells }\end{array}$ & 34 \\
\hline DEX & Melanoma & $\begin{array}{l}\text { Centrifugation up to } \\
100,000 \mathrm{~g} \\
30 \% \text { sucrose } / \mathrm{D}_{2} \mathrm{O} \text { cushion } \\
\text { Treatment with PBS }\end{array}$ & $\begin{array}{l}\text { Exosomal MHC-peptide } \\
\text { complex pulsed with melanoma } \\
\text { antigen } \\
\text { CTL pulsed with melanoma- } \\
\text { primed exosomes + } \\
\text { CpG adjuvants }\end{array}$ & $\begin{array}{l}\text { CpG adjuvants + exosome elicit } \\
\text { immune response toward cancer } \\
\text { cells }\end{array}$ & 62 \\
\hline TEX & $\begin{array}{l}\text { Lymphoma } \\
\text { Leukemia colon }\end{array}$ & $\begin{array}{l}\text { Centrifugation up to } \\
100,000 \mathrm{~g} \\
\text { Treatment with PBS }\end{array}$ & $\begin{array}{l}\text { Direct vaccination of murine } \\
\text { models with TEX and heat- } \\
\text { shocked TEX' }\end{array}$ & $\begin{array}{l}\text { Heat-shocked TEX more } \\
\text { efficacious than TEX alone } \\
\text { Immune response mostly } \\
\text { mediated by CTL }\end{array}$ & 60 \\
\hline TEX & $\begin{array}{l}\text { Colon } \\
\text { melanoma }\end{array}$ & $\begin{array}{l}\text { Centrifugation up to } \\
100,000 \mathrm{~g} \\
\text { Sucrose gradient } \\
\text { Treatment with PBS }\end{array}$ & $\begin{array}{l}\text { DC pulsed with heat-shocked } \\
\text { TEX }\end{array}$ & $\begin{array}{l}\text { Upregulation of } \mathrm{T}_{\mathrm{h}} \mathrm{I} \text {-mediated } \\
\text { tumor response }\end{array}$ & 38 \\
\hline TEX & Colon & $\begin{array}{l}\text { Centrifugation up to } \\
100,000 \mathrm{~g} \\
\text { Sucrose gradient } \\
\text { Treatment with PBS }\end{array}$ & $\begin{array}{l}\text { Human cancer antigen transfected } \\
\text { onto murine TEX }\end{array}$ & $\begin{array}{l}\text { Stimulation of immune cells } \\
\text { Suppression of tumor growth }\end{array}$ & 36 \\
\hline TEX & $\begin{array}{l}\text { CEA- } \\
\text { expressing cells }\end{array}$ & $\begin{array}{l}\text { Centrifugation up to } \\
100,000 \mathrm{~g} \\
30 \% \text { sucrose cushion } \\
\text { Treatment with PBS }\end{array}$ & $\begin{array}{l}\text { Direct vaccination of murine } \\
\text { models with TEX and heat- } \\
\text { shocked TEX' }\end{array}$ & $\begin{array}{l}\text { Heat-shocked TEX confers a } \\
\text { greater immunogenicity } \\
\text { Elicits greater immune } \\
\text { response }\end{array}$ & 60 \\
\hline DEX & Leukemia & $\begin{array}{l}\text { Centrifugation up to } \\
100,000 \mathrm{~g} \\
\text { Treatment with PBS }\end{array}$ & $\begin{array}{l}\text { DC pulsed with cancer cell } \\
\text { antigen } \\
\text { Purified exosomes used } \\
\text { with cyclo-phosphamide + } \\
\text { polyinosinic-polycytidylic acid }\end{array}$ & $\begin{array}{l}\text { Suppression of tumor growth } \\
\text { Induction of spleen cell } \\
\text { proliferation and killing of } \\
\text { cancer cells }\end{array}$ & 49 \\
\hline $\begin{array}{l}\text { DEX and } \\
\text { TEX }\end{array}$ & Lung & $\begin{array}{l}\text { Centrifugation up to } \\
100,000 \mathrm{~g} \\
\text { Treatment with PBS }\end{array}$ & $\begin{array}{l}\text { DC pulsed with cancer cells to } \\
\text { obtain DEX } \\
\text { TEX obtained directly from } \\
\text { cancer cells }\end{array}$ & $\begin{array}{l}\text { DEX elicits a greater CTL anti- } \\
\text { tumor response }\end{array}$ & 50 \\
\hline DEX & Lung & $\begin{array}{l}\text { Centrifugation up to } \\
100,000 \mathrm{~g} \\
\text { Treatment with PBS }\end{array}$ & DC pulsed with cancer cells & $\begin{array}{l}\text { CTL proliferation } \\
\text { Eradication of established tumors } \\
\text { Long-term CTL memory }\end{array}$ & 51 \\
\hline DEX & Lung & $\begin{array}{l}\text { Centrifugation up to } \\
100,000 \mathrm{~g} \\
\text { Treatment with PBS }\end{array}$ & DC pulsed with cancer cells & $\begin{array}{l}\text { Intradermal more efficacious } \\
\text { than subcutaneous administration } \\
\text { Enhanced CTL proliferation }\end{array}$ & 55 \\
\hline
\end{tabular}


Table I (Continued)

\begin{tabular}{|c|c|c|c|c|c|}
\hline $\begin{array}{l}\text { Exosome } \\
\text { type }\end{array}$ & Cancer type & Exosome purification & $\begin{array}{l}\text { Exosome derivation } \\
\text { and delivery }\end{array}$ & Results overview & References \\
\hline DEX & Mesothelioma & $\begin{array}{l}\text { Centrifugation up to } \\
100,000 \mathrm{~g} \\
\text { Treatment with PBS }\end{array}$ & $\begin{array}{l}\text { DC pulsed with tumor cell line } \\
\text { lysate }\end{array}$ & $\begin{array}{l}\text { Antitumor immunity with } \\
\text { prolonged murine model survival } \\
\text { Resistance of secondary tumor } \\
\text { challenge }\end{array}$ & 53 \\
\hline TEX & Pancreatic & $\begin{array}{l}\text { Centrifugation up to } \\
200,000 \mathrm{~g} \\
\text { Treatment with PBS }\end{array}$ & $\begin{array}{l}\text { Interaction of exosomal } \\
\text { nanoparticles with pancreatic } \\
\text { cancer cells induces apoptosis }\end{array}$ & $\begin{array}{l}\text { Induction of apoptosis in } \\
\text { cancer cells via notch signaling }\end{array}$ & 41 \\
\hline TEX & Pancreatic & $\begin{array}{l}\text { Centrifugation up to } \\
200,000 \mathrm{~g} \\
\text { Treatment with PBS }\end{array}$ & $\begin{array}{l}\text { Interaction of exosomal } \\
\text { nanoparticles with pancreatic } \\
\text { cancer cells induces apoptosis }\end{array}$ & $\begin{array}{l}\text { Induction of apoptosis in cancer } \\
\text { cells via PI3K/Akt/GSK-3 } 3 \\
\text { survival pathway }\end{array}$ & 42 \\
\hline DEX & Melanoma & $\begin{array}{l}\text { Centrifugation up to } \\
100,000 \mathrm{~g} \\
30 \% \text { sucrose } / \mathrm{D}_{2} \mathrm{O} \text { cushion } \\
\text { Treatment with PBS }\end{array}$ & $\begin{array}{l}\text { DC pulsed with cancer cells } \\
\text { Addition of cyclo-phosphamide }\end{array}$ & $\begin{array}{l}\text { Antigen-dependent antitumor } \\
\text { effects against pre-existing tumors } \\
\text { via } C D 4^{+} \text {and } C D 8^{+} T \text { cells }\end{array}$ & 52 \\
\hline TEX & VSV & $\begin{array}{l}\text { Centrifugation } \\
\text { Treatment with PBS }\end{array}$ & $\begin{array}{l}\text { Incorporation of VSV antigen } \\
\text { onto exosome } \\
\text { DC pulsed with VSV-exosome } \\
\text { complex }\end{array}$ & $\begin{array}{l}\text { Increased IgG antibody response } \\
\text { Expansion of CTL } \\
\text { Protection from challenge } \\
\text { with ovalbumin expressing } \\
\text { tumor cells }\end{array}$ & 44 \\
\hline DEX & Melanoma & $\begin{array}{l}\text { Centrifugation up to } \\
100,000 \mathrm{~g} \\
30 \% \text { sucrose } / \mathrm{D}_{2} \mathrm{O} \text { cushion } \\
\text { Treatment with PBS }\end{array}$ & DC pulsed with cancer cells & $\begin{array}{l}\text { IL-I5R } \alpha \text {-dependent cell } \\
\text { proliferation } \\
\text { NKG2D-dependent NK } \\
\text { cell activation }\end{array}$ & 54 \\
\hline TEX & Mesothelioma & $\begin{array}{l}\text { Centrifugation up to } \\
100,000 \mathrm{~g} \\
\text { Sucrose gradient } \\
\text { Treatment with PBS }\end{array}$ & DC pulsed with TEX & $\begin{array}{l}\text { Transfer of tumor antigen to DC } \\
\text { Induction of CTL-dependent } \\
\text { antitumor effect }\end{array}$ & 43 \\
\hline TEX & Melanoma & $\begin{array}{l}\text { Centrifugation up to } \\
100,000 \mathrm{~g} \\
\text { Treatment with PBS }\end{array}$ & $\begin{array}{l}\text { TEX engineered to display } \\
\text { membrane-bound HSP70 } \\
\text { DC pulsed with engineered TEX }\end{array}$ & $\begin{array}{l}\text { CTL-mediated antitumor } \\
\text { immunity } \\
\text { NK cell-mediated antitumor } \\
\text { immunity } \\
\text { Membrane-bound HSP70 } \\
\text { TEX more efficacious than } \\
\text { cytoplasmic HSP70 TEX }\end{array}$ & 39 \\
\hline TEX & Lymphoma & $\begin{array}{l}\text { Centrifugation up to } \\
100,000 \mathrm{~g} \\
30 \% \text { sucrose cushion }\end{array}$ & $\begin{array}{l}\text { TEX coated with SEA-TM domain } \\
\text { Direct vaccination of modified } \\
\text { TEX into murine models' }\end{array}$ & $\begin{array}{l}\text { Inhibition of tumor growth } \\
\text { Increased antigen-specific } \\
\text { cytokine secretion by } \\
\text { T cells } \\
\text { SEA-TM-coated TEX elicits } \\
\text { a more potent immune response }\end{array}$ & 59 \\
\hline TEX & $\begin{array}{l}\text { OVA-expressing } \\
\text { tumor cells }\end{array}$ & $\begin{array}{l}\text { Centrifugation up to } \\
100,000 \mathrm{~g} \\
30 \% \text { sucrose cushion }\end{array}$ & $\begin{array}{l}\text { TEX with IL-2 genetic } \\
\text { modification } \\
\text { Direct vaccination of modified } \\
\text { TEX into murine models' }\end{array}$ & $\begin{array}{l}\text { Induction of antigen-specific } \\
\mathrm{T}_{\mathrm{h}} \mathrm{l} \text {-polarized immune response } \\
\text { Activation of } \mathrm{CD} 4^{+} \text {and } \mathrm{CD} 8^{+} \\
\mathrm{T} \text { cells } \\
\text { Activation of NK cells } \\
\text { IL-2 genetic modification } \\
\text { elicits a more potent } \\
\text { immune response }\end{array}$ & 45 \\
\hline TEX & $\begin{array}{l}\text { Fibrosarcoma } \\
\text { OVA-expressing } \\
\text { tumor cell lines }\end{array}$ & $\begin{array}{l}\text { Centrifugation up to } \\
100,000 \mathrm{~g}\end{array}$ & $\begin{array}{l}\text { Incorporation of tumor antigen } \\
\text { onto TEX Direct vaccination of } \\
\text { murine models' }\end{array}$ & $\begin{array}{l}\text { More potent immune response } \\
\text { toward vesicle-bound antigen } \\
\text { than soluble antigen } \\
\text { Mode of secretion can determine } \\
\text { immunogenicity }\end{array}$ & 40 \\
\hline DEX & Adenocarcinoma & $\begin{array}{l}\text { Centrifugation up to } \\
100,000 \mathrm{~g} \\
\text { Treatment with PBS }\end{array}$ & $\begin{array}{l}\text { DC pulsed with tumor peptide } \\
\text { Direct vaccination of murine } \\
\text { models' }\end{array}$ & $\begin{array}{l}\text { Priming of CTL } \\
\text { Eradication and inhibition of } \\
\text { established tumors }\end{array}$ & 46 \\
\hline
\end{tabular}

Note: 'In vivo study.

Abbreviations: PBS, phosphate-buffered saline; SEA-TM, enterotoxin A hydrophobic trans-membrane domain; CEA, carcinoembryonic antigen; DC, dendritic cell; CTL, cytotoxic T lymphocytes; PBL, peripheral blood leukocytes. 
biological immune response by activating $\mathrm{T}$ lymphocytes (via antigen presentation), natural killer (NK) cells (via NKG2D ligand binding), and dendritic cells (via antigen transfer). ${ }^{5}$ The understanding of exosome biology has increased exponentially in recent years, leading to the creation of online databases such as Exocarta, ${ }^{6}$ an encyclopedia dedicated to providing original research findings about exosomes and their associated proteins. ${ }^{7}$

The advent of nanotechnology has generated an immense interest among researchers in its application to medicine. A major goal of the utilization of nanoscale drug delivery systems is to improve its therapeutic index by increasing its potency at specific sites while simultaneously reducing systemic toxicity. ${ }^{8}$ Nanoscale drug delivery systems approved by the US Food and Drug Administration in cancer treatments are currently available, for example, Doxil ${ }^{\circledR}$ (doxorubicin encapsulated in liposomes) ${ }^{9}$ and Abraxane ${ }^{\circledR}$ (paclitaxel attached to nanoparticles). ${ }^{10}$ In addition to being novel drug delivery systems, nanoscale particles can also be specifically engineered to stimulate the immune system, which could form an attractive basis for cancer vaccine development. ${ }^{11}$ There is increasing evidence that nanoscale particles, for example, recombinant virus-like particles (VLPs), inert nanobeads, and immunostimulating complexes, are being utilized in cancer vaccine development due to their effectiveness at eliciting cellular and humoral immune responses. ${ }^{12}$ It has been demonstrated that synthetic nanoparticles could be conjugated to biological molecules (eg, exosomes) and could potentially be used as an effective vaccine delivery system. ${ }^{13}$ Furthermore, there is a growing interest in the utilization of biological molecule delivery systems that serve as conduits to deliver genetic material, drug, or antigen into the body, and attractive candidates are liposomes, VLPs, erythrocyte ghosts, and exosomes (Figure 1). ${ }^{14}$

Thus in this review, we seek to discuss the evidence pertaining to the use of exosomes as a cell-free (hence, conferring

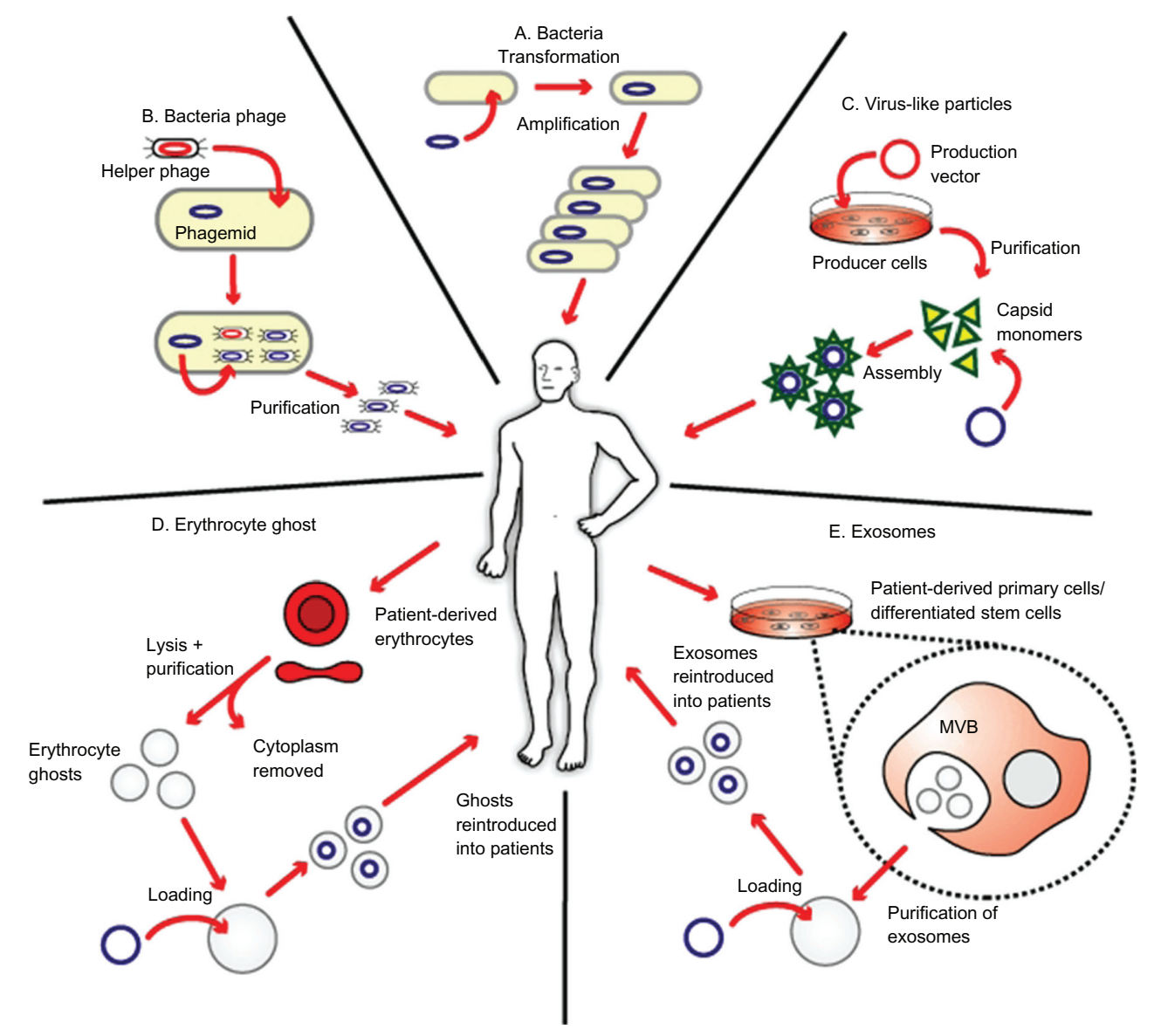

Figure I Biological delivery systems. A) Bacteria can be used for gene delivery, and it is used in cancer gene therapy, DNA vaccination, and treatment of some genetic diseases. B) Bacteriophages are viruses that infect bacteria, and they can be genetically engineered and introduced into bacteria for genetic replication. C) Virus-like particles (VLPs) can be engineered from plasmids coding for viral structure proteins. These VLPs can then be linked to antigens and introduced into the body to elicit an immune response. D) Erythrocyte ghosts are red blood cells that have their cytoplasmic contents removed, and they can be used as vehicles for drug delivery. E) Exosomes are nanoscale vesicles released from dendritic cells and tumor cells, and they can be purified and loaded with antigens and introduced into the body to elicit a cell-specific antitumor response. Copyright (C 2009, Nature Publishing Group. Reproduced with permission from Seow Y, Wood MJ. Biological gene delivery vehicles: beyond viral vectors. Mol Ther. 2009; 17(5):767-777. 
a low immunogenicity and high biosafety profile) nanoscale cancer vaccine and also to explore the potential of combining it with nanotechnology in the hopes of bringing the concept of immunotherapeutic cancer vaccines toward a viable and feasible clinical reality.

\section{The search for a cancer vaccine}

Significant clinical advances have been made in the treatment of cancer using the immune system. One of the best examples of this is the use of donor lymphocyte infusions, which is useful in treating chronic myeloid leukemia. ${ }^{15}$ Bone marrow transplantation has also revolutionized the way hematological malignancies are treated. ${ }^{16}$ However, the search for a true cancer vaccine remains largely elusive. Using cervical cancer as a prime example, current (prophylactic) treatment involves vaccination with either Cervarix ${ }^{\circledR}$ or Gardasil ${ }^{\circledR}$, which are developed from and based on VLP technology, and is useful against cancer-causing variants of human papillomavirus (HPV). ${ }^{17} \mathrm{~A}$ modified strategy using long synthetic HPV oncopeptides has demonstrated that both $\mathrm{CD}^{+}$and $\mathrm{CD}^{+}{ }^{+}$-cell responses can be mounted in vivo and are capable of inducing complete remission in some patients with vulvar cancer. ${ }^{18}$ These results are very encouraging as, for the first time, an antiviral/tumor vaccine has successfully eradicated established tumors. However, these approaches are not 'true' cancer vaccines as an antiviral response is what kills the tumor. In the relentless pursuit of a true cancer vaccine, interesting approaches have been adopted by targeting 'self' proteins on cells that are only expressed at particular sites at specific time frames. ${ }^{19}$ Although these approaches have shown very promising results in murine models, their applicability to humans remain to be seen. In addition, the hepatitis $B$ vaccine protects against hepatitis $B$ virus, which is associated with liver cancer. ${ }^{20}$ Until recently, these so-called 'cancer vaccines' protect against viruses and are prophylactic (must be administered before the viral infection) rather than therapeutic because they do not kill the actual cancer cells.

On April 2010, the Food and Drug Administration approved the use of Provenge ${ }^{\circledR}$ (sipuleucel-T) in the treatment of advanced prostate cancer - the first 'true' therapeutic cancer vaccine that stimulates the body to kill cancer cells by eliciting a biological immune response. ${ }^{21}$ This involves pulsing dendritic cells with prostatic acid phosphatase-containing fusion protein in order to prime the immune system to recognize and kill prostate cancer cells. ${ }^{22}$ In terms of clinical trials in cancer vaccine development in the European Union and United States, ${ }^{23}$ this technique of pulsing dendritic cells with cancer antigen bears stark similarity with the clinical trials involving exosomes reviewed here, and therefore gives credence to the proof-of-concept that the application of exosome could be used as a nanoscale cancer vaccine.

Mounting evidence demonstrates that loading/pulsing dendritic cells with tumor antigens (or TEX) results in higher response rates in cancer patients in terms of eliciting an antitumor-specific immunity, compared to other types of vaccine formulations (eg, peptide vaccines and viral vector vaccines). ${ }^{24}$ This could well form a cornerstone by which cancer vaccines could be effectively developed in the future.

\section{Cancer immunotherapy}

For a cell to become cancerous, it must typically gain an oncogenic function (such as among many others, Myc, Bcl-2, and Ras, which promote cell proliferation), lose its tumor suppressor function (such as p53 and Rb, which promote cell arrest), and be immortalized. ${ }^{25}$ Within the tumor microenvironment, there is extensive interaction between cancer cells and immune cells, and cancer cells may escape immune surveillance by aberrant expression of antigen presentation (eg, lack of MHC I), absence of costimulatory molecules (eg, lack of B7 molecules), and release of immunosuppressive factors (eg, IL-10 and TFG $\beta$ ). ${ }^{26}$ However, the ubiquitous question of why and how the immune system tolerates cancer cells in the first place remains poorly understood and has generated a relentless pursuit toward a search for an immunotherapeutic cancer vaccine.

Dendritic cells (or, more accurately, interdigitating dendritic cells) are professional antigen-presenting cells (APCs), which would be activated upon encountering a foreign agent and would interact with T cells to elicit an antigenspecific immune response. ${ }^{27}$ When immature dendritic cells are activated upon stimulation by foreign antigens, they become mature dendritic cells, which are powerful APCs, priming naïve lymphocytes as well as releasing chemokines to attract $\mathrm{T}$ cells (Figure 2). ${ }^{24}$ In contrast to using monoclonal antibodies in cancer immunotherapy, which is notorious for its systemic side effects like immunosuppression and hypersensitivity reactions due to by stander effects, ${ }^{28}$ dendritic cell-based immunotherapy could function as an attractive alternative for cancer treatment as the immune response mounted is more specific. ${ }^{29}$ Recent evidence shows that artificial APC systems are also emerging as powerful techniques for immunotherapy, and the superior biosafety profile of exosomes has made them an attractive candidate for cancer vaccine development. ${ }^{30}$ 

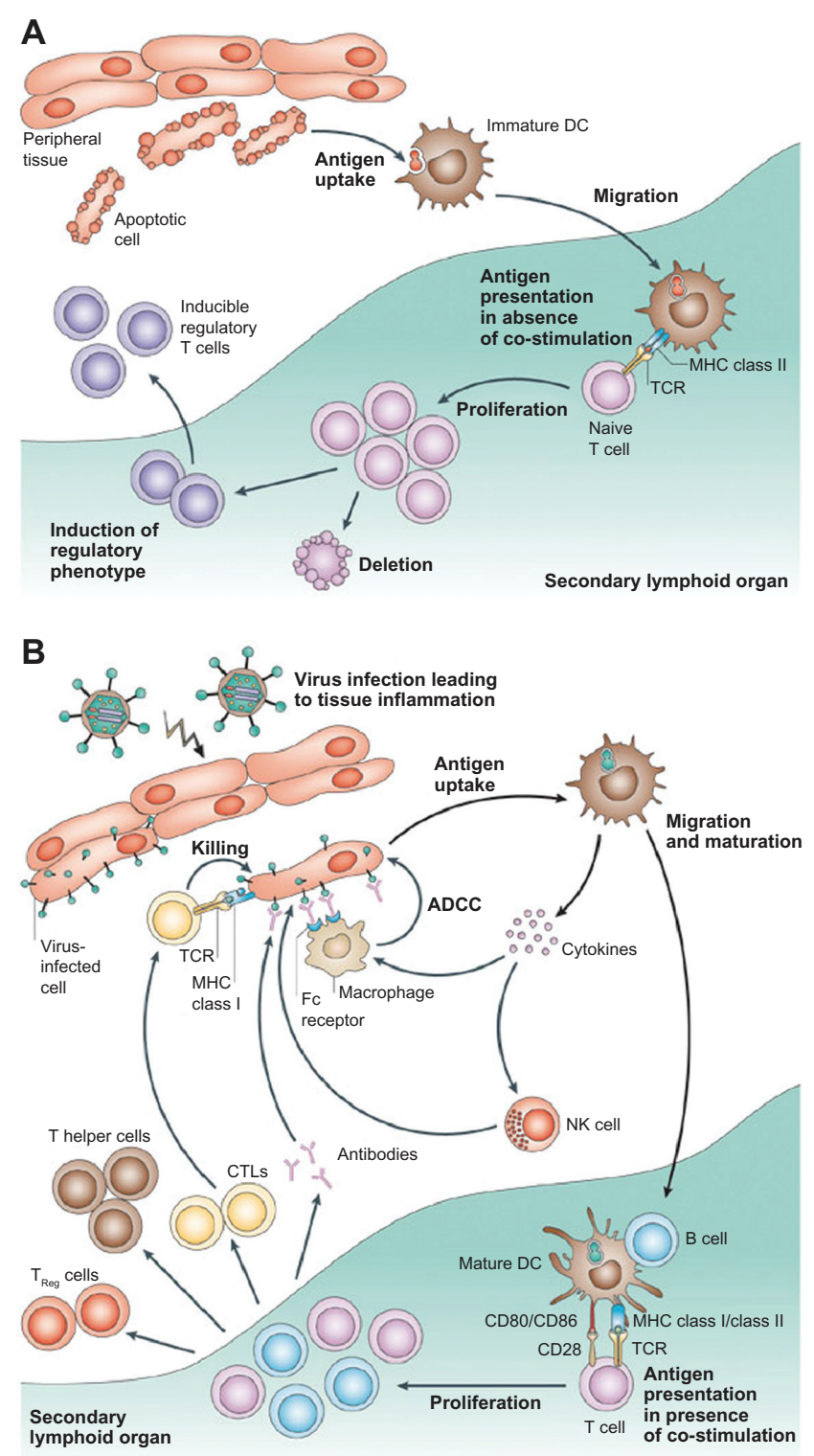

Figure 2 Different functions of immature and mature dendritic cells. A) In the absence of inflammation and costimulation, antigen presentation to immature dendritic cells induces tolerance or anergy (lack of an immune response). This results in deletion or induction of a regulatory phenotype of T cells. B) In the presence of inflammation, immature dendritic cells become activated into mature dendritic cells. Antigen presentation in the presence of costimulatory molecules causes clonal expansion of $\mathrm{CD}^{+}$(helper) and $\mathrm{CD}^{+}$(cytotoxic) T cells and activation of $\mathrm{B}$ cells to produce antibodies and NK cells. Copyright (C) 2005, Nature Publishing Group. Reproduced with permission from Banchereau J, Palucka AK. Dendritic cells as therapeutic vaccines against cancer. Nat Rev Immunol. 2005;5(4):296-306.

\section{A nanoscale and cell-free cancer vaccine}

An ideal cancer vaccine should be able to prime the immune system to recognize specific tumor antigen and then mount an appropriate immune response toward cancer cells without causing 'by stander effect' damage to neighboring cells. ${ }^{31}$ Evidence for such a vaccine remains few and far between, and clinical trials involving cancer vaccines usually yield less-than-satisfactory results, for example, $\operatorname{MyVax}^{\circledR}$ and FavId $^{\circledR}$, which were hailed as 'personalized' vaccines for treating non-Hodgkin's lymphoma, failed to demonstrate any significant therapeutic response. ${ }^{32}$ Although Provenge ${ }^{\circledR}$ represents a milestone in cancer vaccine development, the modest increase in survival time (4.1 months) and the exorbitant cost per patient (about US\$93,000) for three doses of the vaccine demonstrate a need to find novel yet economical ways of cancer vaccine treatment. ${ }^{33}$

Exosomes interact extensively with cells of the immune system, and it has been shown that they activate dendritic cells, thereby priming the immune system to recognize and kill cancer cells (Figure 3). ${ }^{5}$ Exosomes are typically derived and purified using a series of centrifugation steps, not exceeding $100,000 \mathrm{~g}$ on a $30 \% \mathrm{D}_{2} \mathrm{O}$ sucrose cushion. ${ }^{34} \mathrm{AEX}$ taken from peritoneal cavity fluid in cancer patients have been shown to cause tumor cell lysis by inducing dendritic cells to prime T lymphocytes via an MHC I-dependent pathway to kill cancer cells and also triggers the release of IFN- $\gamma$ by peripheral blood lymphocytes in in vitro experimental models (Figure 4). ${ }^{35}$

Similarly, TEX are exosomes purified from cancerous cells. TEX contains tumor antigens, and they have been shown to stimulate cells of the immune system and reduce tumor growth. ${ }^{36}$ There is also evidence pointing toward TEX as tumor and RNA transporters, which could serve as a useful biomarker and diagnostic tool (Figure 5). ${ }^{37}$ It has been shown that TEX expressing heat shock protein-70 (Hsp70) upregulates $\mathrm{T}$ helper cell $1\left(\mathrm{~T}_{\mathrm{h}} 1\right)$-mediated tumor response. ${ }^{38}$ Furthermore, it has also been reported that membrane-bound Hsp70 TEX are more efficacious than cytoplasmic Hsp70 TEX. ${ }^{39}$ Evidence indicates that more potent immune responses are mounted toward vesicle-bound antigen compared to soluble antigen, and the mode of secretion can determine immunogenicity. ${ }^{40}$ Interestingly, induction of apoptosis in cancer cells via notch signaling ${ }^{41}$ and PI3K/Akt/GSK-3 $\beta$ survival pathways $^{42}$ is observed when TEX interacts with pancreatic cancer cells. Apart from stimulating the adaptive immune system by cross-priming cytotoxic $\mathrm{T}$ cells, ${ }^{43}$ it has also been demonstrated that TEX can activate the innate immune system by increasing IgG antibody response $\mathrm{e}^{44}$ and NK cells. ${ }^{45}$

When dendritic cells are pulsed with cancer antigens or tumor peptides, ${ }^{46} \mathrm{DEX}$ has been shown to elicit stronger immune responses toward cancer cells ${ }^{47}$ with upregulation of specific antibody release and cytokine production. ${ }^{48}$ It has also been shown that DEX suppresses tumor growth ${ }^{49}$ and eradication of established tumors ${ }^{50}$ by CD $8^{+} \mathrm{T}$ cells $^{51}$ and $\mathrm{CD} 4^{+}$ 
T cells, ${ }^{52}$ as well as breaking tolerance completely by resistance to secondary tumor challenge.$^{53}$ Furthermore, it has also been reported that NK cells are involved in the immune response toward cancer cells via NKG2D-dependent NK cell activation and IL-15R $\alpha$-dependent cell proliferation. ${ }^{54}$ In terms of the mode of delivery, it has been shown that intradermal injection of DEX is more efficacious than subcutaneous, leading to suggestions that there might be more dendritic cells in the intradermal area than subcutaneous area. ${ }^{55}$

To date, three Phase I clinical trials (China, France, and the United States) have been conducted, involving the application of exosomes to elicit immune responses against established tumors (Table 2). Dai et al ${ }^{56}$ reported that using AEX in patients with colorectal cancer induces

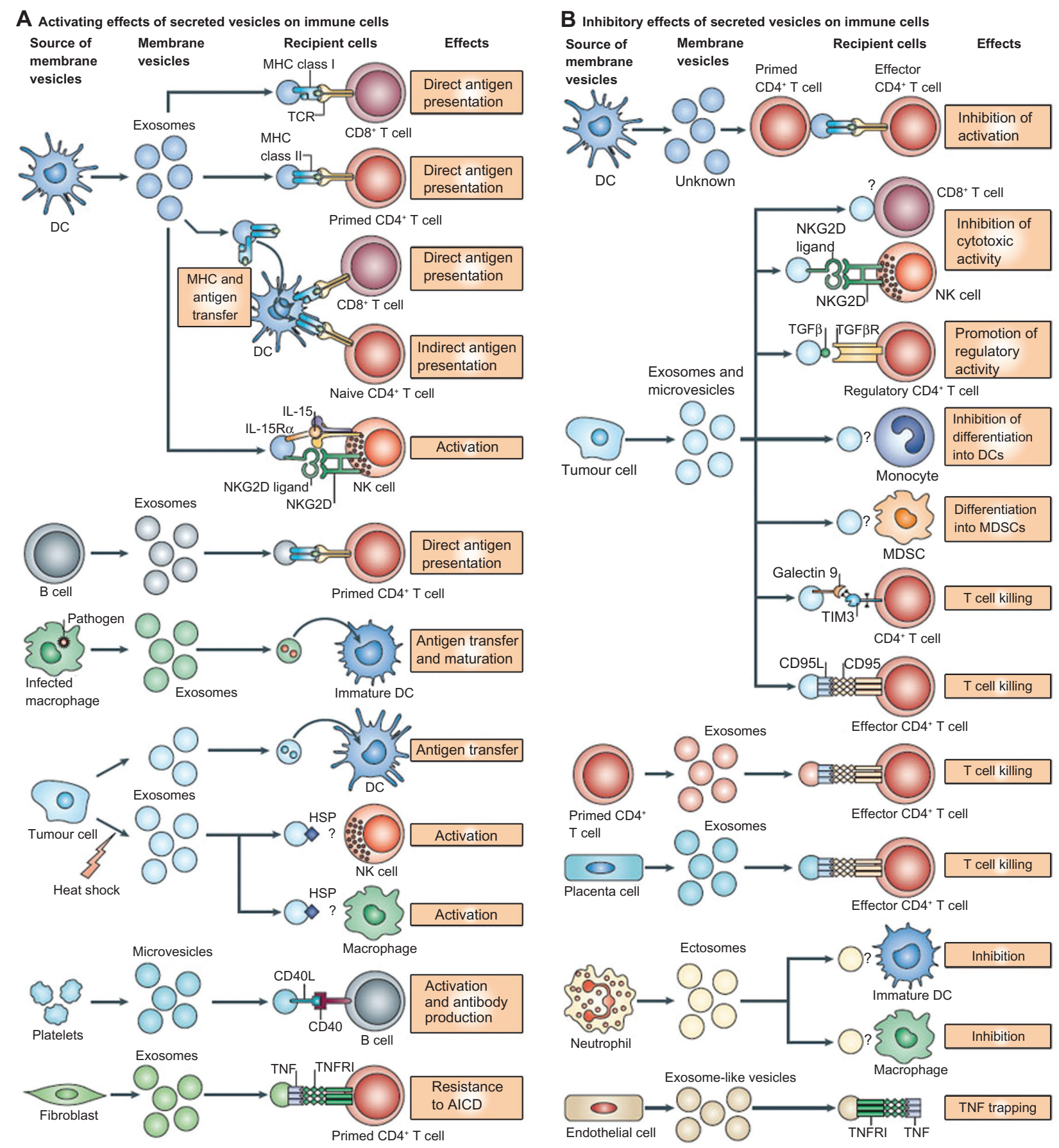

Figure 3 Interactions of exosomes and other nanoscale vesicles with cells of the immune system. A) A variety of cells secrete exosomes, and it can activate different types of immune cells, mainly via antigen presentation. B) Exosomes can also have an inhibitory effect on the immune system, although the mechanisms are not well understood. Copyright @ 2009, Nature Publishing Group. Reproduced with permission from Thery C, Ostrowski M, Segura E. Membrane vesicles as conveyors of immune responses. Nat Rev Immunol. 2009;9(8):58I-593. 


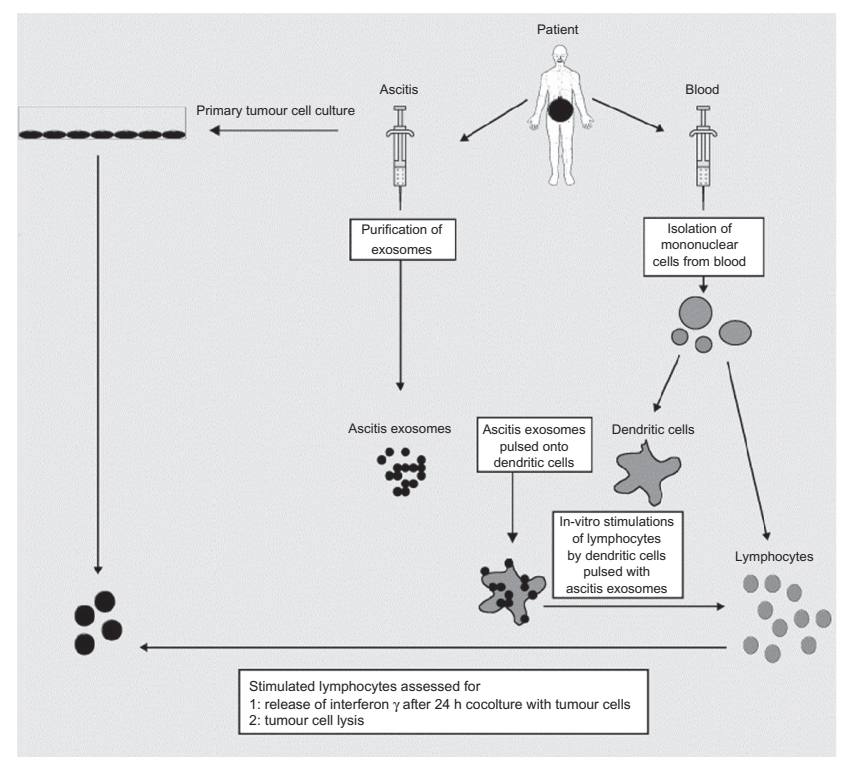

Figure 4 The therapeutic application of AEX. Dendritic cells from peripheral blood monocytes are pulsed with AEX, and cell-specific anti tumor response has been observed. Copyright (C) 2002, Elsevier. Reproduced with permission from Andre F, Schartz NE, Movassagh M, et al. Malignant effusions and immunogenic tumour-derived exosomes. Lancet. 2002;360(9329):295-305.

tumor antigen-specific cytotoxic T-cell responses, with none to minimal side effects, and is well tolerated by patients. Escudier et al $^{57}$ demonstrated the feasibility of scaling up and purification of clinical grade DEX using good manufacturing practice and restored the number and NKG2Ddependent function of NK cells in patients with melanoma (Figure 6). ${ }^{54}$ Furthermore, a study by Morse et al ${ }^{58}$ indicates a MAGE-specific T cell response and increased NK lytic

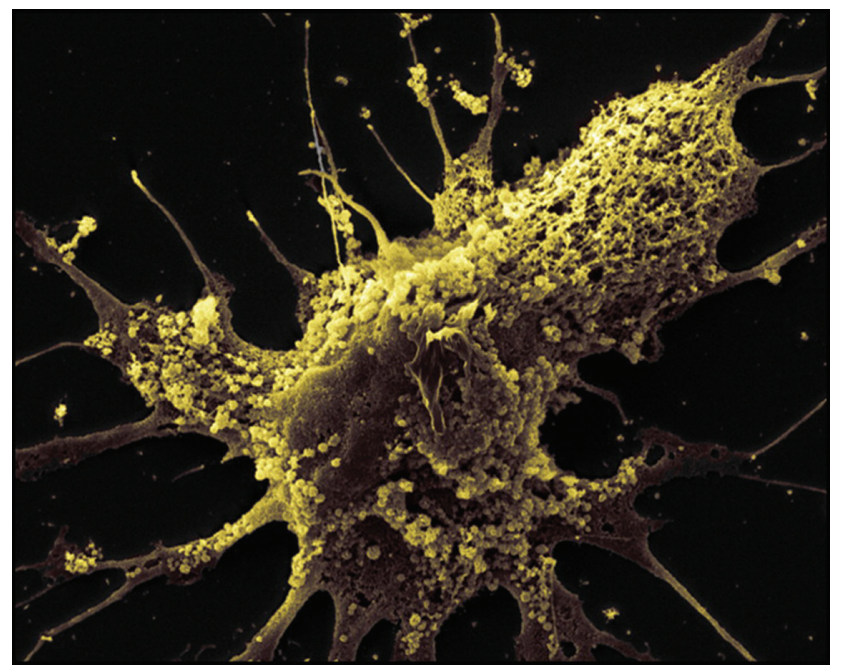

Figure 5 Exosomes are observed on the surface of glioblastoma cells. Tumor-specific peptides or antigens from TEX can be purified and pulsed onto dendritic cells for immunotherapy. Copyright (c) 2008, Nature Publishing Group. Reproduced with permission from Skog J, Wurdinger T, van Rijn S, et al. Glioblastoma microvesicles transport RNA and proteins that promote tumour growth and provide diagnostic biomarkers. Nat Cell Biol. 2008; I0(I2): I470-1476. activity in patients with non-small cell lung carcinoma with the use of DEX.

\section{Challenges and future directions}

Although it has been established from the results in clinical trials that exosomes can be safely administered, their potency in terms of eliciting appropriate immune responses to kill cancer cells leaves much to be desired. The small number of patients involved in the clinical trials calls into question the statistical significance of the results. Most of the experimental evidence reviewed here revolves around solid tumors, and it has not been sufficiently demonstrated that non solid tumors (eg, hematological malignancies) can be treated using exosome technology. Furthermore, taking into account that exosomal immunotherapy relies heavily on the immune system, there remains a need to address the issue of cancer patients who are immunocompromised and/ or immunosuppressed due to chemotherapy and radiotherapy regimens and therefore might not be able to sufficiently surmount cancer cells with their immune system alone.

Understandably, the next major goal is to increase the biological magnitude of the immune response, and this could be achieved perhaps by artificially coating and engineering exosomes ${ }^{59}$ with tumor antigens to make it more recognizable to the immune system. It has also been shown that heat-shocked TEX are more efficacious than TEX alone, ${ }^{60}$ as it confers a greater immunogenicity and elicits a greater immune response, ${ }^{61}$ thereby potentially making it a more effective cancer vaccine. It has also been shown that when CpG adjuvants are added alongside exosome therapy, naïve T cells are more effectively primed. ${ }^{62}$

The application and potential of nanotechnology in medicine heralds a beginning of a new chapter in the treatment of human diseases. Carbon nanotubes (CNTs) are allotropes of carbon, and research reveals that it not only has the potential for imaging and treating cancer cells, it can also be utilized in cancer vaccine delivery systems (Figure 7). ${ }^{63}$ There is evidence to suggest that CNTs, when conjugated to tumor antigens, elicits a specific antitumor response in animal models. ${ }^{64}$ Furthermore, it has been shown that peptide-functionalized CNTs can function as efficient vaccine delivery systems which trigger specific antibody responses. ${ }^{65}$ In addition, it has been experimentally demonstrated that ex vivo clonal expansion of T cells with antibody-linked CNTs results in T-cell activation and might prove to be a novel immunotherapy technique. ${ }^{66}$ There are currently no studies that explore the concept of combining CNTs with exosomes, and this could perhaps function as a novel technique for cancer vaccine 
Table 2 The application of exosomes as a cancer vaccine in Phase I clinical trials

\begin{tabular}{llll}
\hline Cancer type & $\begin{array}{l}\text { No. of } \\
\text { patients }\end{array}$ & $\begin{array}{l}\text { Exosome } \\
\text { type }\end{array}$ & Results \\
\hline Colorectal & 54 & AEX & $\begin{array}{l}\text { Detection of DTH } \\
\text { Induction of tumor-specific antitumor CTL response } \\
\text { AEX + GM-CSF shows higher efficacy }\end{array}$ \\
Melanoma & 15 & DEX & $\begin{array}{l}\text { Demonstrated feasibility of large-scale GMP exosome production } \\
\text { Well tolerated in patients with no major toxicity } \\
\text { Restoration of number and NKG2D-dependent } \\
\text { function of NK cells }\end{array}$ \\
& & & $\begin{array}{l}\text { Demonstrated feasibility of large-scale exosome production } \\
\text { Well tolerated in patients with no major toxicity } \\
\text { NSCLC }\end{array}$ \\
& Stability of disease and activation of immune effectors
\end{tabular}

Abbreviations: CTL, cytotoxic T lymphocytes; GM-CSF, granulocyte-macrophage colony-stimulating factor.

development. Quantum dots (QDs) are also emerging as novel fluorescent probes for imaging and tracking the behavior of cells and nanoscale particles. ${ }^{67}$ QDs are semiconductor nanocrystals of about $2-10 \mathrm{~nm}$ capable of fluorescing at a greater intensity and are more photostable than conventional chromophores. ${ }^{68}$ Considering that exosomes are nanoscale spherical objects, it might also be possible to encapsulate or tether QDs with exosomes in order to image and track their progress in killing cancer cells. ${ }^{69}$ Theoretically, it might also be possible to engineer QDs to fluoresce at different colors to indicate different biological events, and this could be useful in monitoring the interactions of exosomes with $\mathrm{T}$ cells, NK cells, and dendritic cells in order to better understand its antitumor mechanism. ${ }^{70}$ Indeed, it has been experimentally demonstrated that using nanotechnology, exosomes can be engineered to bear an optimal number of MHC I and ligands that would activate $\mathrm{T}$ cells, and its in vivo activity

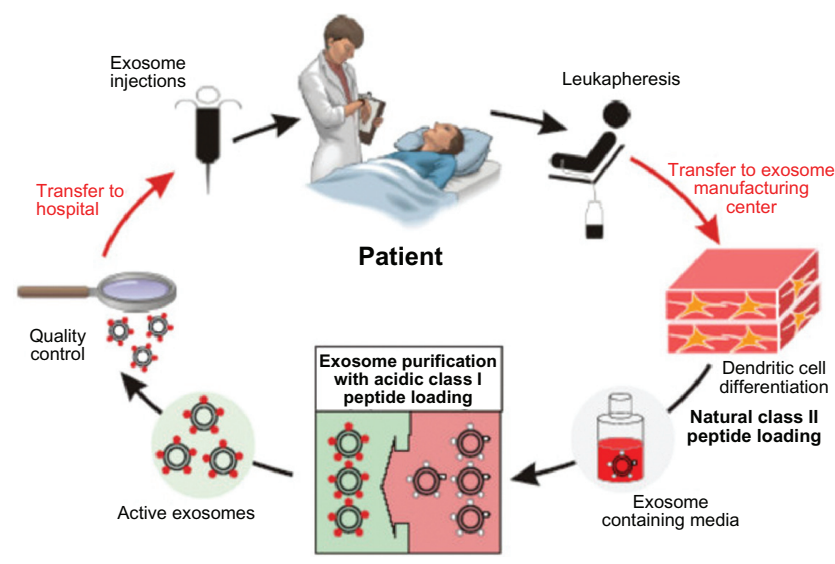

Figure 6 Clinical grade exosomes in immunotherapy. The process of how DEX can be derived, purified, and utilized in cancer treatment. Creative Commons. Reproduced with permission from Escudier B, Dorval T, Chaput N, et al. Vaccination of metastatic melanoma patients with autologous dendritic cell (DC) derived-exosomes: results of the first phase I clinical trial. J Transl Med. 2005;3(I): I0. can be traced by encapsulating superparamagnetic iron oxide nanoparticles (Figure 8). ${ }^{71}$ Exosomes can also carry cytokines, DNA, RNA, adjuvants, labels, costimulatory signals, and gene therapy vectors, which makes it the ultimate Trojan horse. Therefore, engineering the production of exosomes using nanotechnology embodies what we believe is the new platform for cancer vaccines of the future.

A

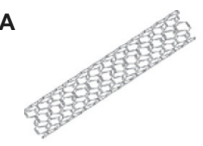

Pristine CNT

B
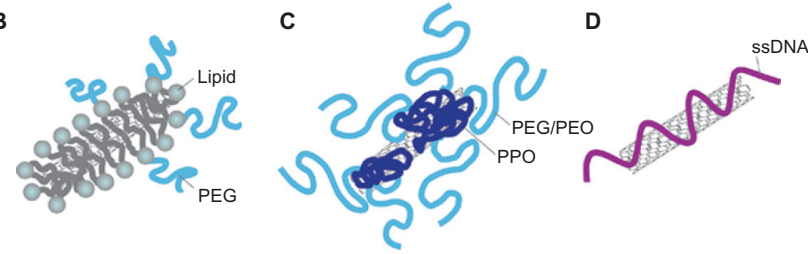

Coated CNTs (non-covalent surface modification)

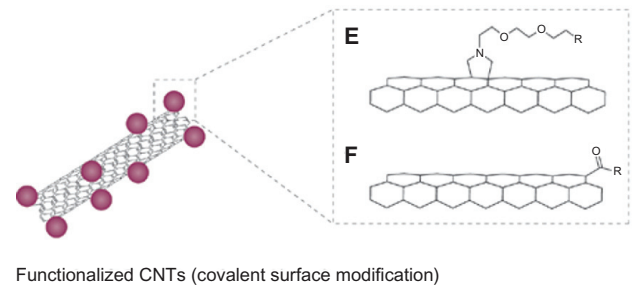

Figure 7 Carbon nanotubes in cancer immunotherapy. A) Pristine CNT is the default setting of CNT, which lacks any bioconjugation or biofunctionalization. They have a strong tendency to aggregate and are mostly used in studies to assess nanotoxicity. B) PEG-conjugated CNT can be used in systemic cancer imaging. C) Copolymer or surfactant-coated CNT with PEO or PPO, and it can be used in localized cancer imaging. D) ssDNA-coated CNT, which aids dispersion and separation. E) Chemically functionalized (covalent surface modification) CNT by I,3 dipolar cycloaddition. F) Chemically functionalized (covalent surface modification) CNT by acid oxidation. Copyright (c) 2009, Nature Publishing Group. Reproduced with permission from Kostarelos K, Bianco A, Prato M. Promises, facts and challenges for carbon nanotubes in imaging and therapeutics. Nat Nanotechnol. 2009;4(10):627-633. Abbreviations: CNT, carbon nanotube; PEG, lipid-polyethylene glycol; PEO, polyethylene oxide; PPO, polypropylene oxide; ssDNA, single-stranded DNA. 

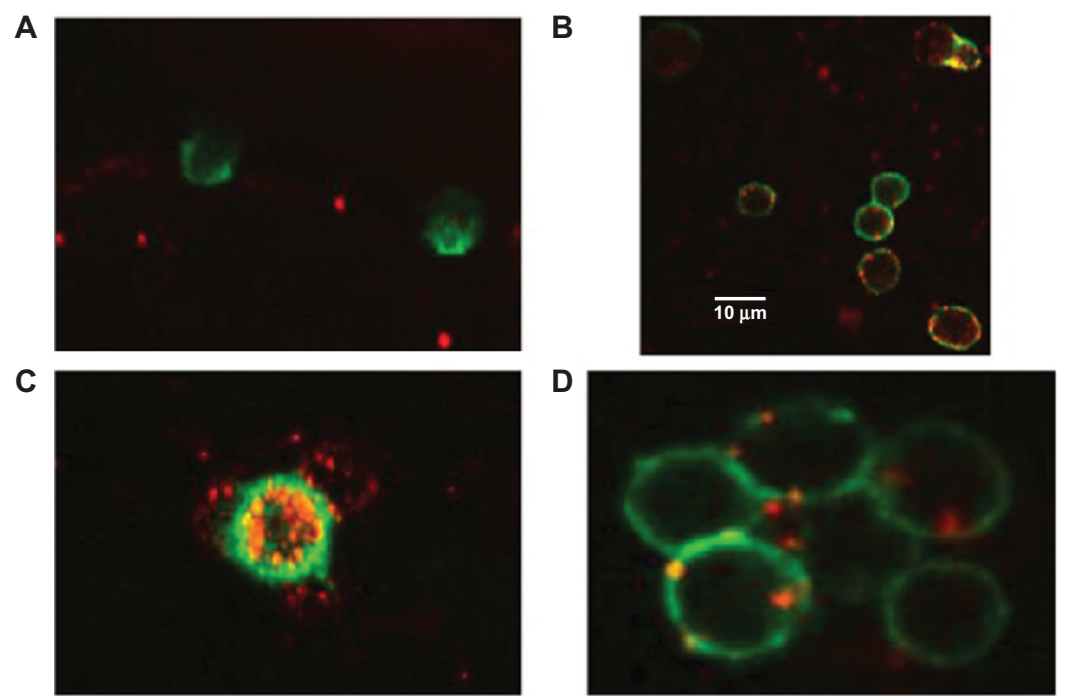

Figure 8 Interaction of engineered exosomes with cells of the immune system. A) Engineered exosomes (red small circles) coated with A2*MHC class I molecules bound to CMV peptides do not bind CD8 ${ }^{+} \mathrm{T}$ cell (stained green) from a CMV positive donor who is HLA A2 negative, showing that exosomes do not bind randomly to T cells and that binding is very much $\mathrm{MHC}$ dependant. B) However, when the same exosomes carrying $\mathrm{A} 2 * \mathrm{MHC} / \mathrm{CMV}$ complexes are cocultured with $\mathrm{T}$ cell from a $\mathrm{CMV}{ }^{+}$and $\mathrm{A2} 2^{+}$donor, direct interaction between exosomes and $C D 8^{+} \mathrm{T}$ cells is clearly seen. $\mathbf{C}$ ) Engineered exosomes (stained red) also bind to natural APCs (stained green and orange when the red and green color overlaps). This figure shows a natural APC activating three different CD8 T cells via engineered exosomes. D) Exosomes bind to APC naturally whether they are engineered or not as the lipids themselves are the binding sites. Copyright @ 2009, Nature Publishing Group. de La Pena H, Madrigal JA, Rusakiewicz S, et al. Artificial exosomes as tools for basic and clinical immunology. J Immunol Methods. 2009;344(2): I2I-132.

\section{Conclusion}

The application of immunotherapy represents a new paradigm in cancer treatment development. The utilization of exosomes in APC systems involving dendritic cells are emerging as powerful techniques to prime the immune system in order to recognize and suppress cancer cell proliferation as well as eradicating established tumors. Despite the modest results of the Phase I clinical trials, the potential for and advancement of the application of exosomes as a nanoscale cancer vaccine are very real. Therefore, larger multicenter clinical trials are needed in order to establish the efficacy of exosomes, and more research has to be conducted to elucidate its mechanism of interaction with the immune system in order to improve its potency. Finally, coupling the use of exosomes with nanotechnology will most likely form the basis where novel nanoscale cancer vaccines will be developed in the future. Taken together, the current literature and the growing body of evidence indicate that exosomes could indeed be utilized as a novel nanoscale and cell-free cancer vaccine, and more research into this area is not only worth pursuing but paramount.

\section{Acknowledgment}

We would like to acknowledge the comments from Professor Jill Helms, University of Stanford.

\section{Disclosure}

The authors report no conflicts of interest in this work.

\section{References}

1. World Health Organization. Cancer. http://www.who.int/mediacentre/ factsheets/fs297/en/index.html. Updated Feb 2009. Accessed 2010 Jun 6.

2. Couzin J. Cell biology: the ins and outs of exosomes. Science. 2005; 308(5730):1862-1863.

3. Iero M, Valenti R, Huber V, et al. Tumour-released exosomes and their implications in cancer immunity. Cell Death Differ. 2008;15(1):80-88.

4. Simpson RJ, Jensen SS, Lim JW. Proteomic profiling of exosomes: current perspectives. Proteomics. 2008;8(19):4083-4099.

5. Thery C, Ostrowski M, Segura E. Membrane vesicles as conveyors of immune responses. Nat Rev Immunol. 2009;9(8):581-593.

6. Exosome protein and RNA database. ExoCarta. Available from: http://exocarta.ludwig.edu.au/. Updated 2010 March 29. Accessed 2010 Jun 23.

7. Mathivanan S, Simpson RJ. ExoCarta: a compendium of exosomal proteins and RNA. Proteomics. 2009;9(21):4997-5000.

8. Malam Y, Loizidou M, Seifalian AM. Liposomes and nanoparticles: nanosized vehicles for drug delivery in cancer. Trends Pharmacol Sci. 2009;30(11):592-599.

9. Leonard RC, Williams S, Tulpule A, Levine AM, Oliveros S. Improving the therapeutic index of anthracycline chemotherapy: focus on liposomal doxorubicin (Myocet). Breast. 2009;18(4):218-224.

10. Petrelli F, Borgonovo K, Barni S. Targeted delivery for breast cancer therapy: the history of nanoparticle-albumin-bound paclitaxel. Expert Opin Pharmacother. 2010;11(8):1413-1432.

11. Zolnik BS, Gonzalez-Fernandez A, Sadrieh N, Dobrovolskaia MA. Nanoparticles and the immune system. Endocrinology. 2010;151(2): 458-465.

12. Scheerlinck JP, Greenwood DL. Virus-sized vaccine delivery systems. Drug Discov Today. 2008;13(19-20):882-887.

13. Rieger J, Freichels H, Imberty A, et al. Polyester nanoparticles presenting mannose residues: toward the development of new vaccine delivery systems combining biodegradability and targeting properties. Biomacromolecules. 2009;10(3):651-657.

14. Seow Y, Wood MJ. Biological gene delivery vehicles: beyond viral vectors. Mol Ther. 2009;17(5):767-777.

15. Biernacki MA, Marina O, Zhang W, et al. Efficacious immune therapy in chronic myelogenous leukemia (CML) recognizes antigens that are expressed on CML progenitor cells. Cancer Res. 2010;70(3):906-915. 
16. Le RQ, Bevans M, Savani BN, et al. Favorable outcomes in patients surviving 5 or more years after allogeneic hematopoietic stem cell transplantation for hematologic malignancies. Biol Blood Marrow Transplant. 2010;16(8):1162-1170.

17. Garland SM, Smith JS. Human papillomavirus vaccines: current status and future prospects. Drugs. 2010;70(9):1079-1098.

18. Kenter GG, Welters MJ, Valentijn AR, et al. Vaccination against HPV-16 oncoproteins for vulvar intraepithelial neoplasia. $N$ Engl J Med. 2009;361(19):1838-1847.

19. Jaini R, Kesaraju P, Johnson JM, Altuntas CZ, Jane-Wit D, Tuohy VK. An autoimmune-mediated strategy for prophylactic breast cancer vaccination. Nat Med. 2010;16(7):799-803.

20. Chen DS. Toward elimination and eradication of hepatitis B. $J$ Gastroenterol Hepatol. 2010;25(1):19-25.

21. US Food and Drug Administration. FDA approves a cellular immunotherapy for men with advanced prostate cancer. Available from: http://www.fda.gov/NewsEvents/Newsroom/PressAnnouncements/ ucm210174.htm. Updated 2010 Apr 29. Accessed 2010 Jun 6.

22. Harzstark AL, Small EJ. Immunotherapy for prostate cancer using antigen-loaded antigen-presenting cells: APC8015 (Provenge). Expert Opin Biol Ther. 2007;7(8):1275-1280.

23. Rethinking therapeutic cancer vaccines. Nat Rev Drug Discov. 2009; 8(9):685-686

24. Banchereau J, Palucka AK. Dendritic cells as therapeutic vaccines against cancer. Nat Rev Immunol. 2005;5(4):296-306.

25. Weinberg R. The Biology of Cancer. 1st ed. London, UK: Garland Science; 2007.

26. Grivennikov SI, Greten FR, Karin M. Immunity, inflammation, and cancer. Cell. 2010;140(6):883-899.

27. Delves PJ, Matin SJ, Burton DR, Roitt IM, editors. Tumour immunology. In: Roitt's Essential Immunology. 11th ed. Oxford, UK: Blackwell Publishing; 2009:402.

28. Hansel TT, Kropshofer H, Singer T, Mitchell JA, George AJ. The safety and side effects of monoclonal antibodies. Nat Rev Drug Discov. 2010 9(4):325-338.

29. Fujii S, Takayama T, Asakura M, Aki K, Fujimoto K, Shimizu K. Dendritic cell-based cancer immunotherapies. Arch Immunol Ther Exp (Warsz). 2009;57(3):189-198.

30. Kim JV, Latouche JB, Riviere I, Sadelain M. The ABCs of artificial antigen presentation. Nat Biotechnol. 2004;22(4):403-410.

31. Koos D, Josephs SF, Alexandrescu DT, et al. Tumor vaccines in 2010: need for integration. Cell Immunol. 2010;263(2):138-147.

32. Sasada T, Komatsu N, Suekane S, Yamada A, Noguchi M, Itoh K Overcoming the hurdles of randomised clinical trials of therapeutic cancer vaccines. Eur J Cancer. 2010;46(9):1514-1519.

33. Tanne JH. FDA approves prostate cancer "vaccine". BMJ. 2010; 340:c2431.

34. Bu N, Li QL, Feng Q, Sun BZ. Immune protection effect of exosomes against attack of L1210 tumor cells. Leuk Lymphoma. 2006;47(5) 913-918.

35. Andre F, Schartz NE, Movassagh M, et al. Malignant effusions and immunogenic tumour-derived exosomes. Lancet. 2002;360(9329): 295-305.

36. Cho JA, Yeo DJ, Son HY, et al. Exosomes: a new delivery system for tumor antigens in cancer immunotherapy. Int J Cancer. 2005;114(4): $613-622$.

37. Skog J, Wurdinger T, van Rijn S, et al. Glioblastoma microvesicles transport RNA and proteins that promote tumour growth and provide diagnostic biomarkers. Nat Cell Biol. 2008;10(12):1470-1476.

38. Cho JA, Lee YS, Kim SH, Ko JK, Kim CW. MHC independent antitumor immune responses induced by Hsp70-enriched exosomes generate tumor regression in murine models. Cancer Lett. 2009;275(2): 256-265.

39. Xie Y, Bai O, Zhang H, et al. Membrane-bound HSP70-engineered myeloma cell-derived exosomes stimulate more efficient CD8(+) CTL- and NK-mediated antitumor immunity than exosomes released from heat-shocked tumor cells expressing cytoplasmic HSP70. J Cell Mol Med. 2009. Jul 20 [Epub ahead of print].
40. Zeelenberg IS, Ostrowski M, Krumeich S, et al. Targeting tumor antigens to secreted membrane vesicles in vivo induces efficient antitumor immune responses. Cancer Res. 2008;68(4):1228-1235.

41. Ristorcelli E, Beraud E, Mathieu S, Lombardo D, Verine A. Essential role of Notch signaling in apoptosis of human pancreatic tumoral cells mediated by exosomal nanoparticles. Int J Cancer. 2009;125(5):1016-1026.

42. Ristorcelli E, Beraud E, Verrando P, et al. Human tumor nanoparticles induce apoptosis of pancreatic cancer cells. FASEB J. 2008;22(9): 3358-3369.

43. Wolfers J, Lozier A, Raposo G, et al. Tumor-derived exosomes are a source of shared tumor rejection antigens for CTL cross-priming. Nat Med. 2001;7(3):297-303.

44. Temchura VV, Tenbusch M, Nchinda G, et al. Enhancement of immunostimulatory properties of exosomal vaccines by incorporation of fusion-competent $\mathrm{G}$ protein of vesicular stomatitis virus. Vaccine. 2008;26(29-30):3662-3672.

45. Yang Y, Xiu F, Cai Z, et al. Increased induction of antitumor response by exosomes derived from interleukin-2 gene-modified tumor cells. J Cancer Res Clin Oncol. 2007;133(6):389-399.

46. Zitvogel L, Regnault A, Lozier A, et al. Eradication of established murine tumors using a novel cell-free vaccine: dendritic cell-derived exosomes. Nat Med. 1998;4(5):594-600.

47. Andre F, Chaput N, Schartz NE, et al. Exosomes as potent cell-free peptide-based vaccine. I. Dendritic cell-derived exosomes transfer functional MHC class I/peptide complexes to dendritic cells. J Immunol. 2004;172(4):2126-2136.

48. Beauvillain C, Ruiz S, Guiton R, Bout D, Dimier-Poisson I. A vaccine based on exosomes secreted by a dendritic cell line confers protection against T. gondii infection in syngeneic and allogeneic mice. Microbes Infect. 2007;9(14-15):1614-1622.

49. Guo F, Chang CK, Fan HH, et al. Anti-tumour effects of exosomes in combination with cyclophosphamide and polyinosinic-polycytidylic acid. J Int Med Res. 2008;36(6):1342-1353.

50. Hao S, Bai O, Yuan J, Qureshi M, Xiang J. Dendritic cell-derived exosomes stimulate stronger CD8+ CTL responses and antitumor immunity than tumor cell-derived exosomes. Cell Mol Immunol. 2006; 3(3):205-211.

51. Hao S, Bai O, Li F, Yuan J, Laferte S, Xiang J. Mature dendritic cells pulsed with exosomes stimulate efficient cytotoxic T-lymphocyte responses and antitumour immunity. Immunology. 2007;120(1): 90-102.

52. Taieb J, Chaput N, Schartz N, et al. Chemoimmunotherapy of tumors: cyclophosphamide synergizes with exosome based vaccines. J Immunol. 2006;176(5):2722-2729.

53. Hegmans JP, Hemmes A, Aerts JG, Hoogsteden HC, Lambrecht BN Immunotherapy of murine malignant mesothelioma using tumor lysatepulsed dendritic cells. Am J Respir Crit Care Med. 2005; 171(10): 1168-1177.

54. Viaud S, Terme M, Flament C, et al. Dendritic cell-derived exosomes promote natural killer cell activation and proliferation: a role for NKG2D ligands and IL-15Ralpha. PLoS One. 2009;4(3):e4942.

55. Hao S, Ye Z, Yang J, Bai O, Xiang J. Intradermal vaccination of dendritic cell-derived exosomes is superior to a subcutaneous one in the induction of antitumor immunity. Cancer Biother Radiopharm. 2006;21(2):146-154.

56. Dai S, Wei D, Wu Z, et al. Phase I clinical trial of autologous ascitesderived exosomes combined with GM-CSF for colorectal cancer. $\mathrm{Mol}$ Ther. 2008;16(4):782-790.

57. Escudier B, Dorval T, Chaput N, et al. Vaccination of metastatic melanoma patients with autologous dendritic cell (DC) derivedexosomes: results of the first phase I clinical trial. J Transl Med. 2005; 3(1): 10 .

58. Morse MA, Garst J, Osada T, et al. A phase I study of dexosome immunotherapy in patients with advanced non-small cell lung cancer. J Transl Med. 2005;3(1):9.

59. Xiu F, Cai Z, Yang Y, Wang X, Wang J, Cao X. Surface anchorage of superantigen SEA promotes induction of specific antitumor immune response by tumor-derived exosomes. J Mol Med. 2007;85(5): $511-521$. 
60. Chen W, Wang J, Shao C, et al. Efficient induction of antitumor T cell immunity by exosomes derived from heat-shocked lymphoma cells. Eur J Immunol. 2006;36(6):1598-1607.

61. Dai S, Wan T, Wang B, et al. More efficient induction of HLA-A*0201restricted and carcinoembryonic antigen (CEA)-specific CTL response by immunization with exosomes prepared from heat-stressed CEApositive tumor cells. Clin Cancer Res. 2005;11(20):7554-7563.

62. Chaput N, Schartz NE, Andre F, et al. Exosomes as potent cell-free peptide-based vaccine. II. Exosomes in $\mathrm{CpG}$ adjuvants efficiently prime naive Tc1 lymphocytes leading to tumor rejection. J Immunol. 2004; 172(4):2137-2146.

63. Kostarelos K, Bianco A, Prato M. Promises, facts and challenges for carbon nanotubes in imaging and therapeutics. Nat Nanotechnol. 2009; 4(10):627-633.

64. Meng J, Meng J, Duan J, et al. Carbon nanotubes conjugated to tumor lysate protein enhance the efficacy of an antitumor immunotherapy. Small. 2008;4(9):1364-1370.

65. Pantarotto D, Partidos CD, Hoebeke J, et al. Immunization with peptidefunctionalized carbon nanotubes enhances virus-specific neutralizing antibody responses. Chem Biol. 2003;10(10):961-966.
66. Fadel TR, Steenblock ER, Stern E, et al. Enhanced cellular activation with single walled carbon nanotube bundles presenting antibody stimuli. Nano Lett. 2008;8(7):2070-2076.

67. van Schooneveld MM, Gloter A, Stephan O, et al. Imaging and quantifying the morphology of an organic-inorganic nanoparticle at the sub-nanometre level. Nat Nanotechnol. 2010;5(7):538-544.

68. Iga AM, Robertson JH, Winslet MC, Seifalian AM. Clinical potential of quantum dots. J Biomed Biotechnol. 2007;2007(10):76087.

69. Jamieson T, Bakhshi R, Petrova D, Pocock R, Imani M, Seifalian AM. Biological applications of quantum dots. Biomaterials. 2007;28(31): 4717-4732.

70. de La Zerda A, Gambhir SS. Drug delivery: keeping tabs on nanocarriers. Nat Nanotechnol. 2007;2(12):745-746.

71. de La Pena H, Madrigal JA, Rusakiewicz S, et al. Artificial exosomes as tools for basic and clinical immunology. J Immunol Methods. 2009; 344(2):121-132.
International Journal of Nanomedicine

\section{Publish your work in this journal}

The International Journal of Nanomedicine is an international, peerreviewed journal focusing on the application of nanotechnology in diagnostics, therapeutics, and drug delivery systems throughout the biomedical field. This journal is indexed on PubMed Central, MedLine, CAS, SciSearch ${ }^{\circledR}$, Current Contents ${ }^{\circledR} /$ Clinical Medicine,

\section{Dovepress}

Journal Citation Reports/Science Edition, EMBase, Scopus and the Elsevier Bibliographic databases. The manuscript management system is completely online and includes a very quick and fair peer-review system, which is all easy to use. Visit http://www.dovepress.com/ testimonials.php to read real quotes from published authors. 